\title{
Nitrogen fixation and abundance of the diazotrophic cyanobacterium Aphanizomenon sp. in the Baltic Proper
}

\author{
Carl Rolff*, Lisa Almesjö, Ragnar Elmgren \\ Department of Systems Ecology, Stockholm University, 10691 Stockholm, Sweden
}

\begin{abstract}
Nitrogen fixation in the Baltic Proper was estimated from the increase in total nitrogen concentration in the upper mixed layer (UML) during summer stratification, using high spatial replication to address the well-known heterogeneity of nitrogen-fixing cyanobacterial blooms. Total nitrogen increase in the UML was found to be $3.2 \mu \mathrm{mol} \mathrm{l^{-1 }}$ in both the Western and Eastern Gotland basins. When corrected for atmospheric deposition and sedimentation, basin-wide Baltic nitrogen fixation (excluding the Gulf of Bothnia) was estimated to be $~ 310$ ktons nitrogen in 2002. Of total nitrogen increase, only $6 \%$ was estimated to remain in the peak biomass of the dominant cyanobacterium Aphanizomenon sp., indicating large leakage of bioavailable, fixed nitrogen. Peak abundance of Aphanizomenon sp. was estimated to be 16 and $14 \mathrm{~m} \mathrm{l}^{-1}$ of filaments in the Western and Eastern Gotland basins, respectively. Results show that the western and eastern basins were similar but comprised considerable spatial heterogeneity at smaller scales. Power analysis was used to estimate the number of replicates required to detect given changes in total nitrogen concentration increase and abundance of Aphanizomenon sp. between 2 yr. This analysis revealed that 10 to 20 replicates are required on a basin-wide scale to detect a $50 \%$ change between years by ANOVA.
\end{abstract}

KEY WORDS: Nitrogen fixation - Aphanizomenon $\cdot$ Nodularia $\cdot$ Baltic $\cdot$ Cyanobacteria $\cdot$ Power analysis

Resale or republication not permitted without written consent of the publisher

\section{INTRODUCTION}

\section{Cyanobacterial blooms in the Baltic Sea}

The Baltic Sea is a brackish, non-tidal, semienclosed sea consisting of 5 major sub-areas (see Fig. 1). Surface salinity ranges from $\sim 2$ PSU in the northernmost Bothnian Bay to 10 PSU in the southwestern part inside the Danish Sounds. Average depth is $\sim 56 \mathrm{~m}$ and the maximum is $459 \mathrm{~m}$. In deeper parts, a permanent halocline at 60 to $80 \mathrm{~m}$ separates surface water from deep water, which regularly experiences severe anoxia when the rate of water exchange with the North Sea is low. Extensive summer blooms of filamentous nitrogen-fixing cyanobacteria occur yearly in the central region (the Baltic Proper). They consist of Aphanizomenon sp. (previously described as A. flosaque but identified as a separate species by Janson et al. 1994), the toxic Nodularia spumigena and, to a lesser extent, Anabaena spp. These blooms are natural to the Baltic and have occurred as far back as $\sim 7000 \mathrm{yr}$ $\mathrm{BP}$, soon after the freshwater Ancylus Lake turned brackish owing to water exchange with the Atlantic Ocean (Bianchi et al. 2000). However, there are indications that blooms have increased in intensity in recent decades (Kahru et al. 1994, Finni et al. 2001, Poutanen \& Nikkila 2001) and, since 1995, blooms of the toxic $N$. spumigena have also extended into the Gulf of Finland where they did not previously form (Kahru et al. 2000). Nitrogen-fixing filamentous cyanobacterial blooms are of concern because they interfere with the recreational use of the sea and because the nitrogen they fix may aggravate Baltic eutrophication.

The main factors favoring the growth of these filamentous cyanobacteria are availability of phosphate, high water temperatures, and a stable water mass 
(Kononen et al. 1996, Kahru et al. 2000, Larsson et al. 2001, Kanoshina et al. 2003). The spring bloom in the Baltic Proper drains the surface water of inorganic nitrogen but leaves sufficient phosphate to give nitrogen-fixing cyanobacteria a competitive advantage over other primary producers. Deep-water anoxia causes the sediments to release phosphate, increasing deep-water phosphate concentration. Major inflows of high salinity water can force this phosphate to the surface, as happened after a major inflow in 2003. This ended a 10 yr deep-water stagnation period, and created preconditions for large nitrogen-fixing blooms. In the warm summer of 2005, a historical and very large Nodularia spumigena bloom followed high surface phosphate levels in spring.

\section{Nitrogen fixation in the Baltic Proper}

Eutrophication caused by the anthropogenic load of nitrogen and phosphorus from 85 million people living in the Baltic drainage area has aggravated anoxia in the deep waters of the Baltic Proper. The external load of nitrogen in the Baltic Sea was recently estimated to be 1000 ktons $\mathrm{N} \mathrm{yr}^{-1}$ (HELCOM 2004), and nitrogen fixation is a substantial additional internal source. Existing estimates of basin-wide nitrogen fixation in the literature (Rahm et al. 2000, Larsson et al. 2001, Wasmund et al. 2001, Schneider et al. 2003, Voss et al. 2005 and sources cited within) range from $\sim 1$ to $318 \mathrm{mmol} \mathrm{N} \mathrm{m}^{-2} \mathrm{yr}^{-1}$ (corresponding to $\sim 3$ to $1000 \mathrm{ktons}$ $\mathrm{N} \mathrm{yr}^{-1}$ ), i.e. from being almost insignificant to equalling the total external nitrogen load. Most recent studies agree that nitrogen fixation contributes a substantial portion to total nitrogen load, but the uncertainties are still large. Since nitrogen-fixing cyanobacteria are favoured by low ratios of inorganic nitrogen to phos- phorus, it is important to quantify basin-wide nitrogen fixation as a basis for correct abatement measures for eutrophication.

Sedimentation of the spring bloom causes an early summer minimum in total nitrogen concentration in the upper mixed layer (UML). In mid-summer a distinct pycnocline develops at 15 to $20 \mathrm{~m}$ in the Baltic Proper, and nitrogen fixation causes the total nitrogen concentration in the UML to increase again to form a late summer maximum. Larsson et al. (2001) used this increase, corrected for atmospheric deposition and sedimentation, to calculate basin-wide nitrogen fixation in the Baltic Proper as 180 to 430 ktons $\mathrm{N} \mathrm{yr}^{-1}$. However, the abundance of nitrogen-fixing filamentous cyanobacteria in the Baltic Proper is spatially very heterogeneous. Remote sensing reveals huge variations in abundance on the scale of $100 \mathrm{~s}$ of $\mathrm{km}$, and drastic variation at much smaller scales is evident when a bloom is observed from ship-deck. When sampling any variable connected to cyanobacterial blooms, spatial variation can thereby be confounded with intra- and interannual differences, making the estimate uncertain. In this study, we estimate the abundance of Aphanizomenon sp. and the summer increase in total nitrogen concentration in the UML using a high level of spatial replication. Integrating from these data, we calculate basin-wide nitrogen fixation and discuss our results in relation to other studies. Because of the central role of nitrogen fixation in Baltic eutrophication, it is important to detect trends in the magnitude of cyanobacterial blooms and their nitrogen fixation within a reasonable time-frame. We therefore use power analysis to estimate the number of samples required to detect prescribed changes in the studied variables.

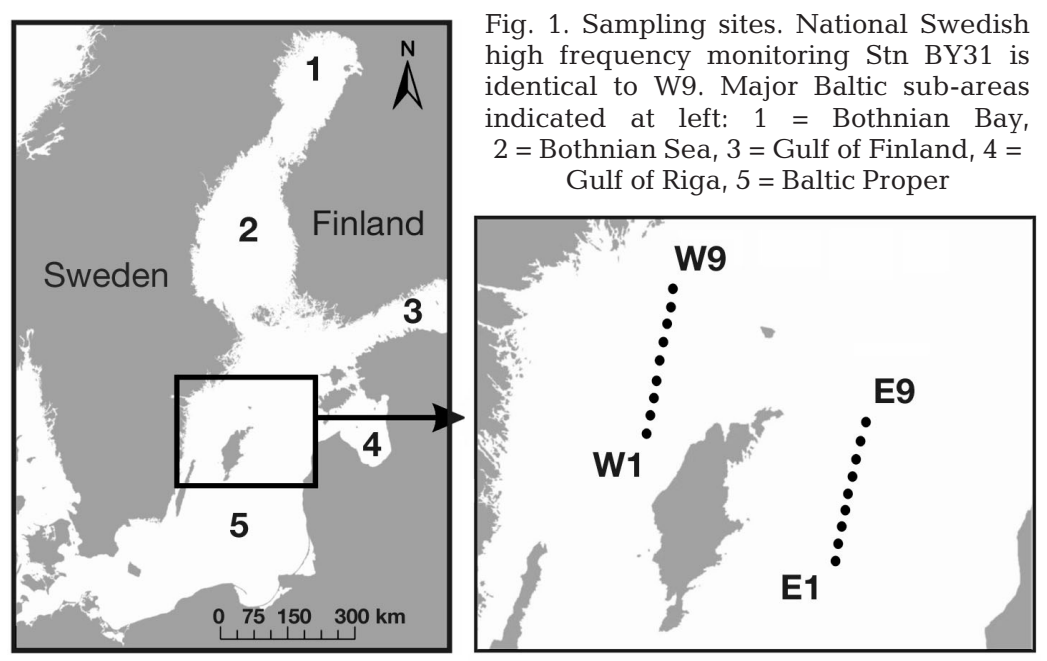

\section{MATERIALS AND METHODS}

Sampling area. In the boreal summer of 2002, we measured total nitrogen concentration in the UML and the abundance of Aphanizomenon sp. at 9 stations each in the north Western Gotland Basin (WGB, Stns W1 to W9) and Eastern Gotland Basin (EGB, Stns E1 to E9) at biweekly (i.e. fortnightly) to monthly intervals, depending on season, in order to cover basin-wide variation (Fig. 1, Table 1). The stations were arranged on an approximate south-to-north route and were $\sim 5$ nautical miles $(\mathrm{nm})$ apart.

Sampling methods. Depth-integrated samples of cyanobacteria in the UML were taken by gently submerging a plas- 
tic hose from the surface down to the pycnocline. This method (Lindahl 1986) is routinely used to sample phytoplankton in the Baltic COMBINE monitoring program of the Helsinki Commission (HELCOM), and was recently evaluated for filamentous cyanobacteria (L. Almesjö \& C. Rolff unpubl.). We used a $20 \mathrm{~m}$ hose (inner diameter $19 \mathrm{~mm}$ ) and emptied its contents ( 5.7 l) into a 201 polycarbonate bottle. To decrease small-scale variation, 3 hoses were pooled and mixed by gentle rotation. A $7 \mathrm{ml}$ syringe sample of unfiltered water was taken for analysis of total nitrogen. This subsampling method using a syringe was evaluated to have coefficients of variation $<2 \%$ for total nitrogen concentration in replicates from the same water sample during the summer period. A $200 \mathrm{ml}$ sub-sample for numeration of Aphanizomenon sp. filaments was also immediately preserved with $0.9 \mathrm{ml}$ acetic Lugol's solution. The national Swedish monitoring program also samples by hose, but samples are unpooled and each sample therefore represents the contents of 1 hose.

Hose samples are generally not used for chemical analyses in the HELCOM program. To prevent contamination, we used an armoured PVC hose with a high quality inert inner lining of food grade polyethylene, which had been rinsed with tap water ( 2.5 bar) for $24 \mathrm{~h}$, and controlled for effect on total nitrogen by allowing tap water to remain in the hose for $10 \mathrm{~min}$. No differences were detected between water obtained directly from the tap and water from the hose. The hose was fitted with a $5 \mathrm{~kg}$ stainless steel tube at the submersed end to enhance sinking. It was plugged with machine-washed silicon plugs between samplings and rinsed 5 times at each station by submerging and emptying it immediately before sampling.

Analytical methods. Total nitrogen concentration was analysed in unfiltered water by persulphate digestion followed by flow injection analysis (QuikChem 31107-04-1-B). The abundance of Aphanizomenon sp. was estimated with a newly developed image analysis method (L. Almesjö \& C. Rolff unpubl.) as well as with conventional Utermöhl counting (Utermöhl 1958). The image analysis method was developed to reduce the time required for numeration and to generate more detailed information on filament morphology. Samples were allowed to settle for $\sim 24 \mathrm{~h}$ in counting chambers (25 or $50 \mathrm{ml}$, depending on filament abundance). Twenty images per sample were recorded with a black and white CCD video camera (Sony XC-75CE) connected to an inverted light microscope (Leica DM IRB) and a PC. A macro written in the image analysis software Leica Qwin identified Aphanizomenon sp. filaments by comparing the dimensions of all objects with pre-set threshold values, and the correctness of identification was visually confirmed. The dimensions length, width, area and position were measured for all accepted objects (i.e. those fitting within the threshold values). To ensure precision in image analysis measurements, $25 \%$ of the samples were also manually counted with the Utermöhl (1958) method. The agreement between estimates of filament length from the image analysis method and the manual Utermöhl counts was excellent (regression $\mathrm{R}^{2}=0.98, \mathrm{p}<0.001$ ). The Aphanizomenon sp. abundances presented in this study are image analysis measurements, except for those from Sampling Occasion 3 (July 1-2) when large quantities of straight Anabaena spp. reduced the reliability of image analysis measurements as a result of overlap in filament dimensions with Aphanizomenon sp. All samples from this occasion were therefore counted with the traditional Utermöhl method, as are samples in the national Swedish monitoring program.

Filament length is reported in metres per litre $\left(\mathrm{m} \mathrm{l}^{-1}\right)$, which is a very exact abundance estimate because the error of length estimates in image analysis is very small. The distribution of individual filament lengths was skewed to the right (arithmetic mean $191 \mu \mathrm{m}$, geometric mean $159 \mu \mathrm{m}$ per filament), whereas the width of filaments was approximately normally distributed around $4.5 \mu \mathrm{m}$. Since the relative measurement error in width is considerably greater than for length, conversion to biomass is a less exact abundance estimate. An approximate conversion to carbon can be made using the factor $1.5 \mathrm{pg} \mathrm{C} \mathrm{m}^{-1}$ of filament (Edler 1979, Kononen et al. 1996).

Statistical methods. Statistical analyses were conducted with Statistica 6.1. Differences between sampling occasions were tested by ANOVA. Data were transformed to fulfil ANOVA assumptions of variance homogeneity and normally distributed residuals, as tested by Cochran's $C$-test and by normal probability plots of within-cell residuals. Post hoc tests for differences among means were made by Tukey's Honestly Significant Difference (HSD) test. Total nitrogen samples from Stns W7 and E7 on May 7-8 were missing, and for this ANOVA Tukey's HSD test for unequal N was used. Aphanizomenon sp. filament abundance could not be transformed to variance homogeneity for both basins in the same analysis, and was therefore tested by basin-wise ANOVA after $\log (y+1)$ transformation. A single extreme value from Stn W9 (July 23) was excluded.

\section{RESULTS}

\section{Oceanographic background data at monitoring Stn BY31}

The annual cycles of temperature and nutrients were typical of the northern Baltic Proper (Fig. 2). Sedimentation of the spring bloom in March-April depleted the 


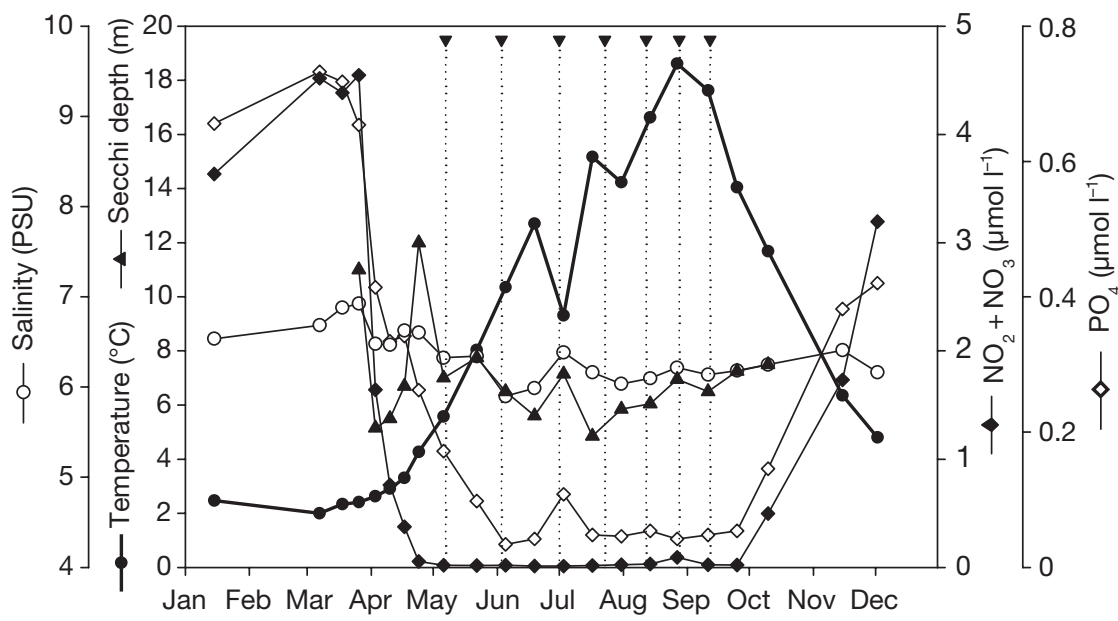

Fig. 2. Salinity, mean temperature, Secchi depth and concentrations of oxidized inorganic nitrogen and phosphate in the upper $20 \mathrm{~m}$ (mean of depths $0,5,10,15$ and $20 \mathrm{~m}$ ) at Stn BY31 (= W9) in 2002. Sampling dates of the present study indicated by $\boldsymbol{\nabla}$ with dotted lines

UML of inorganic nitrogen. Phosphate concentrations also decreased drastically, but a low concentration $(\sim 0.05 \mu \mathrm{M})$ remained during summer (however, at such low levels, it is unclear if the phosphate analysis reflects actual availability of phosphate). Phosphate surplus favours diazotrophic cyanobacteria, which are generally considered to be phosphorus-limited in the Baltic (Niemi 1979, Larsson et al. 2001, Rydin et al. 2002, Moisander et al. 2003). The temperature of the UML above the thermocline at 15 to $20 \mathrm{~m}$ depth increased to a maximum in July-August (Figs. 2 \& 3) with a minor upwelling event in late June. Salinity varied around 6 PSU with no clear seasonal variation.

\section{Total nitrogen concentrations in the UML and abundance of Aphanizomenon sp.}

Total nitrogen showed a remarkably similar time-pattern in the WGB and EGB (Fig. 4a, Table 1), but concentrations were on average $1.3 \mu \mathrm{mol} \mathrm{N} \mathrm{I}^{-1}$ higher in the eastern basin. ANOVA tests indicated significant differences for both sampling dates and basins (Table 2), but no interaction effects. In both areas, the lowest concentration was recorded on the first sampling occassion (May 7-8) and the peak on the fourth sampling occasion (July 23-24). The concentration increase was continuous in both basins, and most rapid between the second and third sampling occasions (between June 3 and July 1). In the WGB, the concentration increased from 19.9 to $23.2 \mu \mathrm{mol} \mathrm{N} \mathrm{^{-1 }}$, and in the

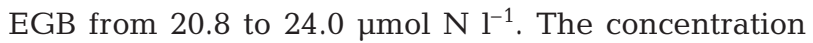
increase of $\sim 3.2 \mu \mathrm{mol} \mathrm{N}{ }^{-1}\left(\sim 64 \mathrm{mmol} \mathrm{N} \mathrm{m}^{-2}\right)$ in both basins corresponded to $0.83 \mathrm{mmol} \mathrm{N} \mathrm{m}^{-2} \mathrm{~d}^{-1}$ for the period from May 7 to July 23.

The abundance of Aphanizomenon sp. (Fig. 4b, Table 1) was also similar between the WGB and EGB. Data from both basins could not be transformed to variance homogeneity in a factorial ANOVA. Differences between basins could therefore not be statistically tested, but appear to be small (Fig. 4b). Both basins showed highly significant differences among sampling dates (Table 3). Between

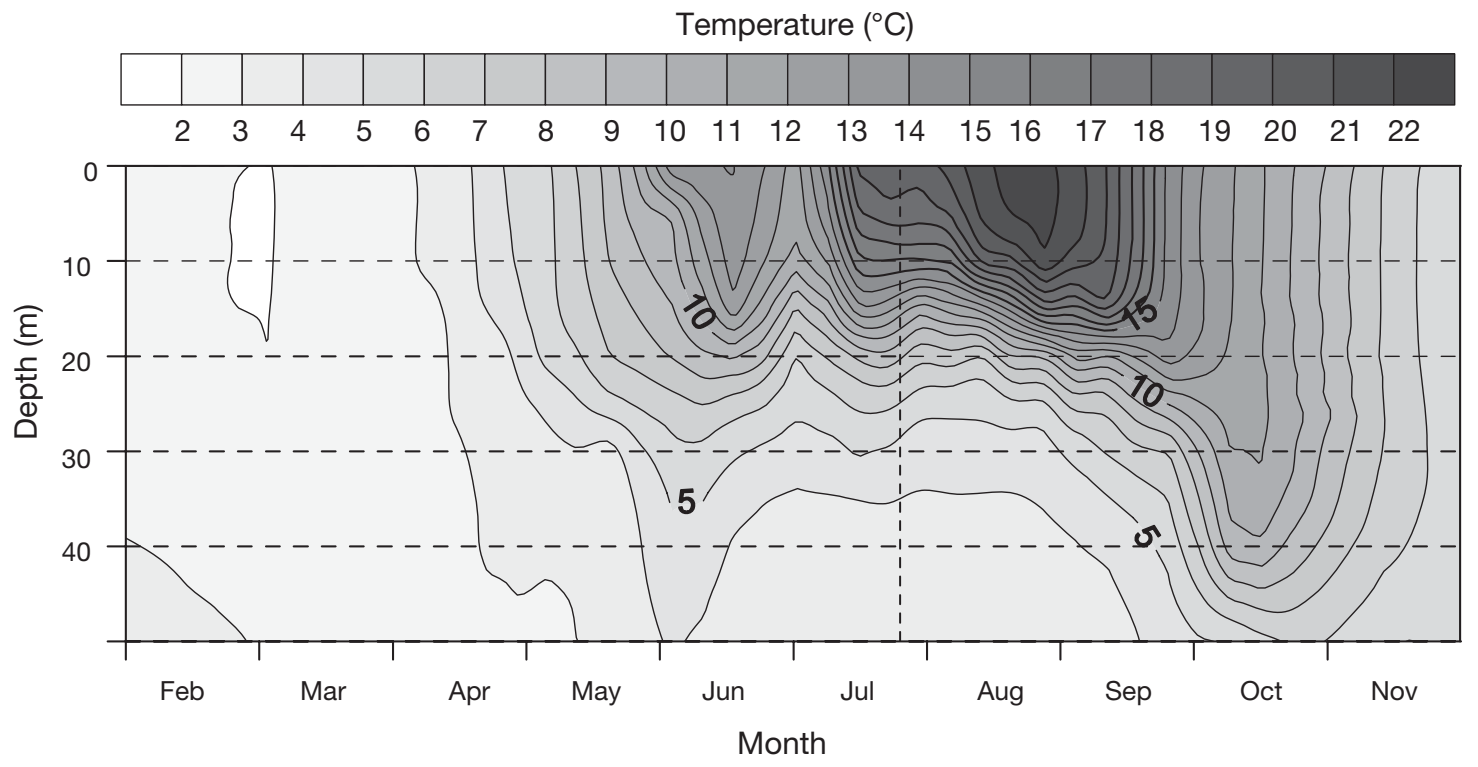

Fig. 3. Water temperature at Stn BY31 (= W9) in 2002. Vertical dashed line indicates total nitrogen peak 
Table 1. Sample dates, mean (SD) concentrations of total nitrogen and mean (SD) abundance of Aphonizomenon sp. filaments in the upper $20 \mathrm{~m}$ of 9 stations per basin in 2002

\begin{tabular}{|c|c|c|c|c|c|}
\hline \multicolumn{3}{|c|}{ Western Gotland Basin (WGB) } & \multicolumn{3}{|c|}{ Eastern Gotland Basin (EGB) } \\
\hline Date & 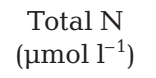 & $\begin{array}{l}\text { Abundance } \\
\left(\mathrm{m} \mathrm{l}^{-1}\right)\end{array}$ & Date & 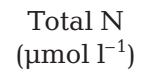 & $\begin{array}{l}\text { Abundance } \\
\left(\mathrm{m} \mathrm{l}^{-1}\right)\end{array}$ \\
\hline 7 May & $19.9(0.82)$ & $1.5(0.63)$ & 8 May & $20.8(0.34)$ & $2.3(0.77)$ \\
\hline 3 Jun & $20.4(1.40)$ & $7.6(3.00)$ & 4 Jun & 21.5 (1.15) & $6.8(6.81)$ \\
\hline $1 \mathrm{Jul}$ & $22.2(2.03)$ & $16.0(6.59)$ & $2 \mathrm{Jul}$ & $23.8(1.49)$ & $14.0(3.77)$ \\
\hline $23 \mathrm{Jul}$ & $23.2(1.24)$ & $12.3(6.40)$ & $24 \mathrm{Jul}$ & $24.0(1.79)$ & $13.7(3.14)$ \\
\hline $12 \mathrm{Aug}$ & $20.5(1.31)$ & 2.9 (1.05) & 13 Aug & $22.9(1.02)$ & $3.1(3.41)$ \\
\hline 28 Aug & $21.3(1.51)$ & $2.0(1.94)$ & 29 Aug & $22.3(1.04)$ & $2.5(3.98)$ \\
\hline 12 Sep & $21.1(1.21)$ & $1.7(0.49)$ & 13 Sep & $22.6(1.54)$ & $0.8(0.34)$ \\
\hline
\end{tabular}

$\left.\mathrm{p}_{\mathrm{EGB}}=0.62\right)$. The bloom then declined rapidly to $<2 \mathrm{~m} \mathrm{l}^{-1}$ in early September (Fig. 4b). The standard deviations (SDs) of abundance estimates were large (Table 1 , see 'Discussion').

The similarity between WGB and EGB suggests that the dynamics of total nitrogen in the UML (and hence nitrogen fixation) and Aphanizomenon sp. abundance in the 2 basins is reasonably similar. However, the large SDs (Table 1) indicate considerable spatial heterogeneity at smaller scales. Total nitrogen concentrations were consistently slightly higher in

May 7-8 and July $1-2$, the abundance of Aphanizomenon sp. increased from 1.5 to $16 \mathrm{~m} \mathrm{l}^{-1}$ in the WGB and from 2.3 to $14 \mathrm{~m} \mathrm{l}^{-1}$ in the EGB, and peaked (July 1) before total nitrogen concentration (July 23) in both basins. From July 1-2 to July 23-24, the abundance declined slightly but this reduction was not statistically significant (Post hoc: $\mathrm{p}_{\mathrm{WGB}}=0.58$,
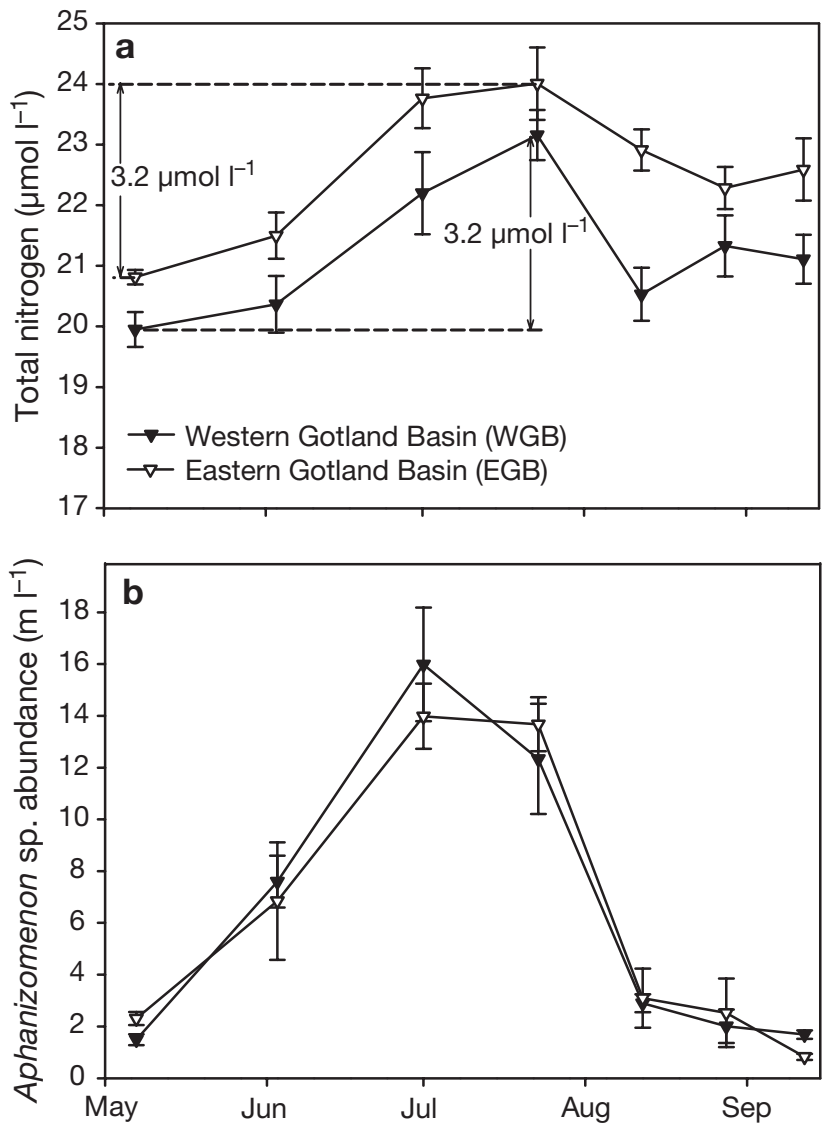

Fig. 4. (a) Concentration of total nitrogen in unfiltered water and (b) abundance of Aphanizomenon sp. filaments. Means $( \pm$ SE) are of upper $20 \mathrm{~m}$ of 9 stations per basin (WGB and EGB) in 2002
EGB. Summer concentrations of total nitrogen in the UML are generally higher in the central Baltic Proper than in the northern part. This possibly reflects high nitrogen loads from the large southern Baltic rivers and/or the intensity of nitrogen fixation (the largest surface accumulations of Nodularia spumigena visible in satellite images are often observed in the central part). However, in the present study, the highest abundances of Aphanizomenon sp. were found in the southern part of WGB (Fig. 5) and were, at the abundance maximum, generally slightly higher in the northern part of EGB than in the southern part (Fig. 5).

Table 2. ANOVA of total nitrogen concentrations in the UML. Data are untransformed

\begin{tabular}{|lrrrrc|}
\hline Factor & SS & df & MS & $F$ & $p$ \\
\hline Date & 126.49 & 6 & 21.08 & 11.58 & $<0.001$ \\
Basin & 53.82 & 1 & 53.82 & 29.56 & $<0.001$ \\
Interaction & 8.02 & 6 & 1.34 & 0.73 & 0.62 \\
Residual & 200.32 & 110 & 1.82 & & \\
\hline
\end{tabular}

Table 3. Aphanizomenon sp. Basin-wise ANOVA of abundance. Data were $\log _{10}(y+1)$ transformed to fulfil ANOVA assumptions but could not be transformed to variance homogeneity for both basins in the same analysis. Therefore, the difference between basins could not be strictly tested but appears small (Fig. 4b)

\begin{tabular}{|c|c|c|c|c|c|}
\hline Factor & SS & $\mathrm{df}$ & MS & F & $\mathrm{p}$ \\
\hline \multicolumn{6}{|c|}{ Western Gotland Basin (WGB) } \\
\hline Date & 5.87 & 6 & 0.98 & 33.13 & $<0.001$ \\
\hline Residual & 1.62 & 55 & 0.030 & & \\
\hline \multicolumn{6}{|c|}{ Eastern Gotland Basin (EGB) } \\
\hline Date & 7.05 & 6 & 1.18 & 21.29 & $<0.001$ \\
\hline Residual & 3.09 & 56 & 0.55 & & \\
\hline
\end{tabular}




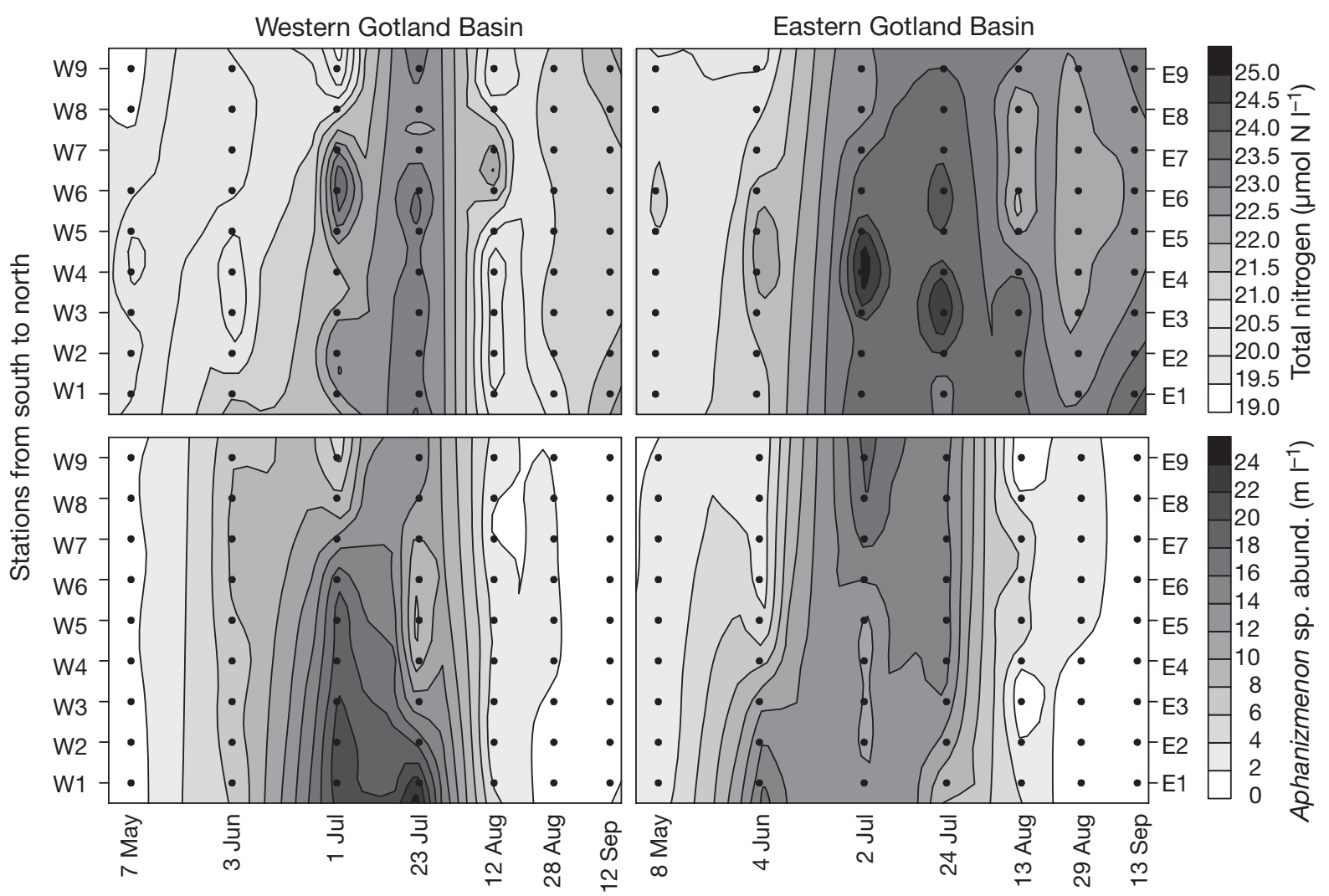

Fig. 5. Time-space plots of total nitrogen and abundance of Aphanizomenon sp. filaments at 9 stations per basin (WGB and EGB). Stations indicated from south (bottom) to north (top)

\section{DISCUSSION}

\section{Sources and sinks of summer total nitrogen}

The increase in total nitrogen by $64 \mathrm{mmol} \mathrm{N} \mathrm{m}^{-2}$ must be adjusted for inputs and losses in order to estimate nitrogen fixation. There was no net total nitrogen input to the UML by transport across the pycnocline, because total nitrogen concentration was lower below the cline. Atmospheric deposition is an important input term but there are few published estimates for the entire Baltic Proper. The annual deposition of nitrogen in the Baltic Proper was reviewed and synthesised by modelling by Granat (2001). He estimated wet and dry deposition of total nitrogen at 4.8 to $6 \mathrm{mmol} \mathrm{N}$ $\mathrm{m}^{-2} \mathrm{mo}^{-1}$. Wasmund et al. (2001) cited unpublished summer estimates of M. Schulz and colleagues of $\sim 0.1 \mathrm{mmol} \mathrm{N} \mathrm{m}^{-2} \mathrm{~d}^{-1}$, whereas Larsson et al. (2001) estimated $\sim 6 \mathrm{mmol} \mathrm{N} \mathrm{m}^{-2} \mathrm{mo}^{-1}$ based on yearly deposition data of Lindfors et al. (1993), but also cited a lower estimate of M. Schultz and colleagues of $\sim 4 \mathrm{mmol} \mathrm{N} \mathrm{m}^{-2}$ $\mathrm{mo}^{-1}$. Schneider et al. (2003) estimated $\sim 0.1 \mathrm{mmol} \mathrm{N}$ $\mathrm{m}^{-2} \mathrm{~d}^{-1}$ based on data from HELCOM. C. Rolff et al. (unpubl. data) measured an average June-to-August summer nitrogen deposition of $\sim 3.6 \mathrm{mmol} \mathrm{N} \mathrm{m}^{-2} \mathrm{mo}^{-1}$ at 4 Baltic stations in 2001 and 2002. These estimates agree quite well, and we used $4 \mathrm{mmol} \mathrm{N} \mathrm{m}{ }^{-2} \mathrm{mo}^{-1}$ to correct for atmospheric deposition.

The correction for losses by seasonal nitrogen sedimentation adds more uncertainty than that for atmospheric deposition. Because of their buoyancy, direct sedimentation of filamentous cyanobacteria is generally low (Heiskanen \& Kononen 1994, Sellner 1997), and grazing on cyanobacteria appears to be negligible in the Baltic (Sellner et al. 1994). Even though primary production is high, the sedimentation of particulate matter is lower in summer than in other seasons. Unpublished data of M. Olesen et al. (cited in Larsson et al. 2001 and Wasmund et al. 2001) indicate a JulyAugust sedimentation of particulate organic nitrogen (PON) of 1 to 1.2 (Larsson et al. 2001) or 0.8 to 1.4 (Wasmund et al. 2001) $\mathrm{mmol} \mathrm{m}^{-2} \mathrm{~d}^{-1}$ in the open Baltic Proper. From N:P ratios in sediment trap material and the summer decrease in dissolved total phosphorous concentration in the UML, Larsson et al. (2001) calculated a minimum nitrogen loss of 0.33 to $0.6 \mathrm{mmol} \mathrm{m}^{-2}$ $\mathrm{d}^{-1}$. After recalculating carbon sedimentation and correcting for resuspension, Larsson et al. (2001) assumed a net sedimentation of 0.8 to $1.4 \mathrm{mmol} \mathrm{N} \mathrm{m} \mathrm{m}^{-2}$. These estimates agree well with an estimate of $0.8 \mathrm{mmol} \mathrm{N}$ 
$\mathrm{m}^{-2} \mathrm{~d}^{-1}$ from the south-west coast of Finland (Heiskanen et al. 1998), which we used to estimate sedimentation loss. All sedimentation estimates from sediment traps are fraught with uncertainties of resuspension and non-representative trapping. Using ${ }^{234} \mathrm{Th}$ as a tracer, Gustafsson et al. (2004) found sediment traps to underestimate slowly settling organic-rich aggregates by a factor of 3 to 10 . Another potential loss is denitrification, but this was found to be negligible in blooms (Tuomainen et al. 2003).

\section{Basin-wide nitrogen fixation estimates}

The most productive stage of a bloom lasts about 6 wk, during which atmospheric deposition can be assumed to contribute $6 \mathrm{mmol} \mathrm{N} \mathrm{m}{ }^{-2}(1.5 \mathrm{mo} \times 4 \mathrm{mmol}$ $\mathrm{N} \mathrm{m}^{-2} \mathrm{mo}^{-1}$ ) to the UML, and settling loss can be estimated as $34 \mathrm{mmol} \mathrm{N} \mathrm{m}{ }^{-2}\left(42 \mathrm{~d} \times 0.8 \mathrm{mmol} \mathrm{N} \mathrm{m}^{-2} \mathrm{~d}^{-1}\right)$. The estimate of nitrogen fixation in this study thus becomes $64-6+34=92 \mathrm{mmol} \mathrm{N} \mathrm{m}{ }^{-2}$. Wasmund et al. (2001) reviewed the literature and found estimates ranging from $\sim 1$ to $320 \mathrm{mmol} \mathrm{N} \mathrm{m} \mathrm{yr}^{-1}$. However, more recent estimates were in the range of 62 to $263 \mathrm{mmol} \mathrm{N} \mathrm{m}^{-2} \mathrm{yr}^{-1}$. Rahm et al. (2000) estimated an average fixation for the Baltic Proper of 14.3 to $214 \mathrm{mmol} \mathrm{N} \mathrm{m}{ }^{-2} \mathrm{yr}^{-1}$ by calculating fixed nitrogen from phosphate consumption and the Redfield N:P ratio. From total summer nitrogen increase in the UML in 1994 to 1998, Larsson et al. (2001) calculated fixation to be in the range of 61 to $140 \mathrm{mmol} \mathrm{N} \mathrm{m} \mathrm{Nr}^{-1}$, whereas Wasmund et al. (2001) used ${ }^{15} \mathrm{~N}$-tracer methods to measure nitrogen fixation directly and obtained estimates between 101 and 263 with an average of $125 \mathrm{mmol} \mathrm{N} \mathrm{m}^{-2} \mathrm{yr}^{-1}$. A much higher estimate (318 $\mathrm{mmol} \mathrm{N} \mathrm{m}^{-2} \mathrm{yr}^{-1}$ ) was obtained by Schneider et al. (2003), who calculated nitrogen fixation from changes in the $\mathrm{CO}_{2}$ budget of the water mass. However, this calculation postulated an input of 100 to $200 \mathrm{mmol} \mathrm{N}$ $\mathrm{m}^{-2}$ during spring, which was contradicted by repeated ${ }^{15} \mathrm{~N}_{2}$ measurements taken in this period (Wasmund et al. 2005). Recent studies that directly measured nitrogen fixation, or nitrogen increase during a bloom, all arrive at $\sim 100 \mathrm{mmol} \mathrm{N} \mathrm{m}{ }^{-2} \mathrm{yr}^{-1}$ as a likely estimate.

To compare nitrogen fixation with other nitrogen inputs to the Baltic Sea, an approximate basin-wide annual estimate can be calculated. Dense nitrogenfixing blooms occur mainly in the central areas of the Baltic Sea. The volume above $20 \mathrm{~m}$ in the Baltic Proper (including the southern parts of the Åland and Archipelago Seas, the Arkona area and the Belt Sea), Gulf of Finland and Bay of Riga (Fig. 1) was calculated using a bathymetric grid to be $\sim 4850 \mathrm{~km}^{3}$. The corresponding approximate area, assuming a homogenous $20 \mathrm{~m}$ depth, is $240000 \mathrm{~km}^{2}$. This may overestimate the cyano- bacterial bloom area by 10 to $15 \%$, because blooms are less prevalent in the Bay of Riga, inner Gulf of Finland and the Arkona Basin. On the other hand, Aphanizomenon sp. blooms of lower intensity also occur in the Bothnian Sea $\left(\sim 66000 \mathrm{~km}^{-2}\right)$. Larsson et al. (2001) calculated 5 yr means for nitrogen fixation, which were similar in all studied areas of the Baltic Proper except for a higher value in the Bornholm basin. Assuming homogeneous nitrogen fixation in the Baltic Proper, our measurement can be used to estimate total fixation to be $\sim 310$ ktons $\mathrm{N} \mathrm{yr}^{-1}$. This exceeds previous esti-

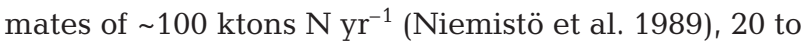
190 ktons $\mathrm{N} \mathrm{yr}^{-1}$ (Hübel \& Hübel 1995) and 30 to 260 ktons $\mathrm{N} \mathrm{yr}^{-1}$ (Rahm et al. 2000), but agree well with estimates of 180 to 430 ktons $\mathrm{N} \mathrm{yr}^{-1}$ by Larsson et al. (2001) and 370 ktons $\mathrm{N} \mathrm{yr}^{-1}$ by Wasmund et al. (2001). Of the total estimated external nitrogen load of

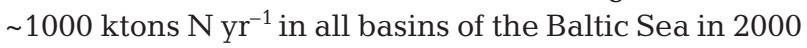
(HELCOM 2004), 440 ktons $\mathrm{N} \mathrm{yr}^{-1}$ was waterborne inputs from diffuse anthropogenic sources, $\sim 260 \mathrm{ktons}$ $\mathrm{N} \mathrm{yr}^{-1}$ atmospheric deposition, $\sim 240$ ktons $\mathrm{N} \mathrm{yr}^{-1}$ natural background load, and $\sim 75 \mathrm{ktons} \mathrm{Nr}^{-1}$ point sources. The Baltic nitrogen fixation estimated in this study was accordingly larger than the atmospheric deposition and natural external load, and almost of the same magnitude as the anthropogenic load from diffuse sources. Therefore, a change in rate of nitrogen fixation is likely to substantially affect the eutrophication of the Baltic. Should the high estimate of Schneider et al. (2003) be correct, nitrogen fixation would equal all other sources taken together. However, this would imply a greater increase in total nitrogen in the UML than seen so far or a much higher sedimentation loss. Most calculations of nitrogen fixation are quite sensitive to assumptions concerning sedimentation. A $50 \%$ greater sedimentation rate, which is still within the possible range (Larsson et al. 2001, Wasmund et al. 2001), would boost the nitrogen fixation calculated here to 365 ktons $\mathrm{N} \mathrm{yr}^{-1}\left(108 \mathrm{mmol} \mathrm{N} \mathrm{m}{ }^{-2} \mathrm{yr}^{-1}\right)$.

How representative is the 2002 estimate of annual nitrogen fixation when compared to other years? Cyanobacteria have been sampled with high frequency at the national Swedish monitoring station BY31 (=W9) since 1990. The Aphanizomenon sp. bloom at this station occurs within the months June to September, and peak abundances are generally found in July. Spatial variability makes it difficult to compare peak abundances among years. Transport of water masses may also cause drastic changes between consecutive sampling occasions. Nitrogen fixation is likely to be dependent not only on the abundance, but also on the duration of a bloom. High abundance of short duration may result in lower nitrogen fixation than a long bloom with lower abundances. Within the period May 28 to September 30 the biweekly monitoring pro- 


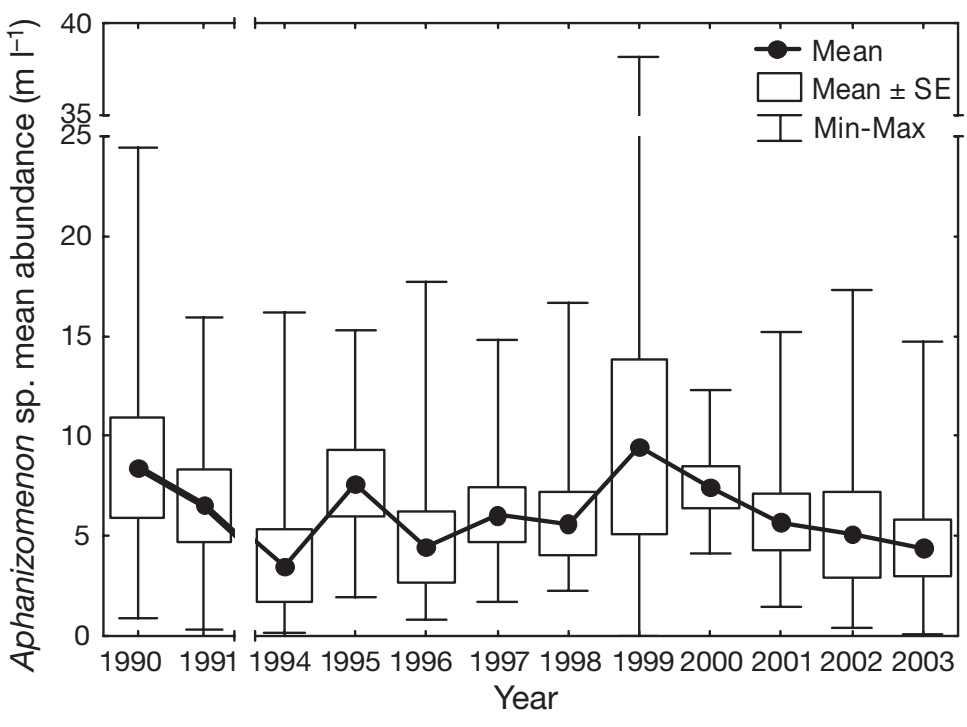

Fig. 6. Aphanizomenon sp. Mean $(\bullet) \pm$ SE (boxes) of yearly summer (May 28 to September 30) filament abundance at Stn BY31 (= W9) from 1990 to 1991 and from 1994 to 2003 (9 estimates per summer). Whiskers $=$ min. and max. abundance; note scale breaks on both axes

gram sampled on 9 occasions, and the average abundance during this period can be used as an approximation of bloom size (Fig. 6). The average abundance of the 2002 bloom was $\sim 5 \mathrm{~m} \mathrm{l}^{-1}$, which is slightly below the average for all years $\left(\sim 6 \mathrm{~m} \mathrm{l}^{-1}\right)$; the maximum yearly average was observed in $1999\left(\sim 9.5 \mathrm{~m} \mathrm{l}^{-1}\right)$ with a very high maximum abundance. Another way to approximate the bloom is to integrate the area below the abundance curve for the same dates (not shown). The results were quite similar and suggest that the 2002 bloom was slightly below normal bloom-size for the years 1990 to 2003 and can therefore be considered representative. It is, however, important to note that the abundance of Nodularia spumigena was not evaluated owing to its extreme patchiness, which makes abundance estimates unreliable.

\section{Distribution of fixed nitrogen in particulate and dissolved nitrogen}

Average Aphanizomenon sp. abundance in the UML (top $20 \mathrm{~m}$ ) was $15 \mathrm{~m} \mathrm{l}^{-1}$ at the peak of the bloom (July 1), corresponding to $\sim 0.45 \mathrm{~g} \mathrm{C} \mathrm{m}^{-2}$ (see 'Materials and methods'). Larsson et al. (2001) observed the molar C:N ratio of filamentous cyanobacteria (mixed Nodularia spumigena and Aphanizomenon sp.) at the peak of the bloom to be $\sim 6.5$. Using this ratio, the peak population of Aphanizomenon sp. (the dominant nitrogen fixer in the northern Baltic Proper) should contain $\sim 0.08 \mathrm{~g} \mathrm{~N} \mathrm{~m}^{-2}$. Thus, only $\sim 6 \%$ of the estimated nitrogen fixation of $1.29 \mathrm{~g} \mathrm{~N} \mathrm{~m}^{-2}\left(92 \mathrm{mmol} \mathrm{N} \mathrm{m}^{-2}\right)$ was assumed to remain in the filaments at the peak of the bloom. Since only Aphanizomenon sp. filaments were estimated, and not the other major bloom species Nodularia spumigena, this will underestimate the amount of fixed nitrogen remaining in the biomass of the nitrogen fixers. Monitoring data from the northern and central Baltic generally show that Aphanizomenon sp. dominates the biomass and has a more extended bloom period. If the amount of nitrogen contained in $N$. spumigena is assumed to be at most equally large, a maximum of $12 \%$ of fixed nitrogen would remain in the biomass of both species. There is ample evidence that diazotrophic cyanobacteria fix more nitrogen than needed to sustain their growth (Capone et al. 1994, Glibert \& Bronk 1994, Ohlendieck et al. 2000, Rolff 2000, Larsson et al. 2001, Gallon et al. 2002). The excess nitrogen can be released as $\mathrm{NH}_{4}{ }^{+}$or as amino acids (Capone et al. 1994, Gallon et al. 2002). Further support for this hypothesis is given by the fact that the abundance maxima of Aphanizomenon sp. in 2002 preceded the nitrogen concentration maxima in both basins. Filamentous cyanobacteria appear to be unpalatable and little grazed in the Baltic (Sellner et al. 1994), and are therefore unlikely to directly support much consumer production. However, by supplying limiting nitrogen in bioavailable forms during summer, they should stimulate production by other phytoplankton, and thereby eventually fish production.

\section{Detecting changes in cyanobacterial blooms}

Since nitrogen fixation by blooms is clearly a major source of nitrogen in the Baltic Proper, changes in the extent of blooms could potentially result in large changes in the input of nitrogen. Since the mid-1990s, severe anoxia in the deep waters of the Baltic Proper has caused increased phosphate release from sediments, and by 2003-2005 this excess phosphate had reached the surface, where high concentrations were measured even after the spring bloom. Potentially, an increase in phosphate availability, whether from sediment release or direct anthropogenic load, could increase the intensity of summer cyanobacterial blooms. In summer 2005, a very large bloom of Nodularia spumigena occurred in the Baltic Proper, probably caused by very warm, calm weather in July, in combination with the phosphate surplus in surface water. The bloom caused extensive, foul-smelling surface scums, which interfered with recreational water activities and fishing, and the potential toxicity of N. spumigena created public concern. Although exceptional, 
the 2005 bloom is not without historic precedent (Lindström 1855, Finni et al. 2001). The pressure for management actions to limit the extent of such blooms has therefore increased, and reliable monitoring of blooms must be considered a top priority.

Cyanobacterial blooms in the Baltic Proper are spatially highly heterogeneous (Kahru et al. 1994, Wasmund et al. 2001, Kanoshina et al. 2003). Through their buoyancy, they accumulate as surface scums in calm weather conditions. In intermediate wind conditions, Langmuir circulation causes them to aggregate in stripes, whereas Ekman transport may affect the blooms in large areas. During extended periods of high winds they become more evenly distributed in the water mass, but may re-accumulate at the surface once calm returns. This tendency to aggregate can cause huge abundance differences on scales ranging from metres to many nautical miles, which creates statistical problems when attempting to compare bloom intensity among years. Therefore, little is reliably known about the long-term time trends of blooms at basin-wide scales (Kahru et al. 1994, Wasmund 1997, Finni et al. 2001, Wasmund \& Uhlig 2003). There are, however, some indications that blooms (particularly the abundance of Nodularia spumigena) have increased in intensity in recent decades (Kahru et al. 1994, Finni et al. 2001, Poutanen \& Nikkilä 2001).

The filamentous diazotrophic cyanobacteria found in the Baltic can regulate their buoyancy to some extent (e.g. Walsby et al. 1997), and short-term differences in depth distribution caused by variations in buoyancy may in surface samples be interpreted as abundance variation over time. In the Baltic, only Nodularia spumigena regularly accumulates in surface scums; Aphanizomenon sp. is generally more evenly distributed in the water column, with an abundance maximum around 6 to $10 \mathrm{~m}$ (Hajdu et al. 2007). We estimated abundance only for Aphanizomenon sp. because the method of sampling with an integrating hose produced high variability among replicates for N. spumigena (L. Almesjö \& C. Rolff unpubl.). Surface accumulations seen in satellite images are dominated by $N$. spumigena (Kahru et al. 1994), and remote sensing may therefore be useful in assessing the abundance of this species. Since the abundance maximum of Aphanizomenon sp. is generally too deep for detection by satellite, little is known about the large-scale spatial distribution of this species, which generally greatly dominates samples of filamentous cyanobacteria in the northern Baltic Proper (Larsson et al. 2001). The high level of replication in our data can be used to calculate power for detecting changes in nitrogen fixation (estimated as change of total nitrogen in the UML) and in Aphanizomenon sp. abundance.
Most monitoring programs take a single sample at each station on each sampling occasion. With this design it is not possible to separate temporal variation from small-scale spatial variation. Because no stationspecific variance estimate is obtained on each sampling occasion, it is not possible to test for differences among years at specific stages of the bloom. It is only possible to test an average of values during bloom development, which confounds intraannual variation with interannual variation, and decreases the power of the test. The problems of using a single station to estimate bloom development become clear when inspecting the time series for individual stations (Fig. 7). Large differences were observed among individual stations, and even neighbouring stations exhibited marked differences in total nitrogen concentrations (e.g. W6 and W7, E5 and E6). The abundance peak of Aphanizomenon sp. was more synchronous in the western basin than in the eastern, but even here conspicuous differences were observed e.g. between W6 and W9. In EGB the peak appeared to be later in the north than in the south (Fig. 5), but there are also exceptions at Stns E4 and E5, where the total nitrogen peak preceded the Aphanizomenon sp. peak. Without the high level of replication used in the present study, it would not have been possible to obtain the clear results presented in Fig. 4. The estimate of spatial variance makes it possible to separate the components of spatial and temporal variance.

From the estimate of spatial variance we can calculate the minimum number of replicates needed to detect a given change between 2 years by ANOVA with a certain power (Sokal \& Rohlf 2000), where $80 \%$ is often used as an acceptable limit for detection. The power parameter $\Phi$ is calculated from the minimum detectable difference and the $\mathrm{SD}$, according to

$$
\Phi=\left[\left(\mathrm{n} \delta^{2}\right) \times\left(2 a \mathrm{SD}^{2}\right)^{-1}\right]^{0.5}
$$

where $\mathrm{n}$ is the number of replicates, $\delta$ is the desired minimum effect to be detected and $a$ is the number of treatments (in this case $2 \mathrm{yr}$ ). The number of replicates required is determined by an iterative procedure and a power table of $\Phi$ or by software. If the change between peak and preceding minimum of total nitrogen and abundance of Aphanizomenon sp. is our detection variable, we can calculate the number of replicates required to detect a given change in these variables between 2 years, assuming that sampling is performed with a sufficient frequency to identify a maximum.

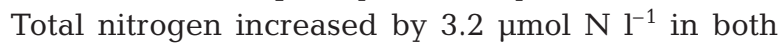
basins and the best estimate of variability is the pooled SD of 1.54 (WGB: 1.24, EGB: 1.79). In order to detect (for instance) a $50 \%$ greater concentration increase in another year by ANOVA, we must be able to separate a peak concentration that is $1.6 \mu \mathrm{mol} \mathrm{N} \mathrm{l^{-1 }}(0.5 \times$ 


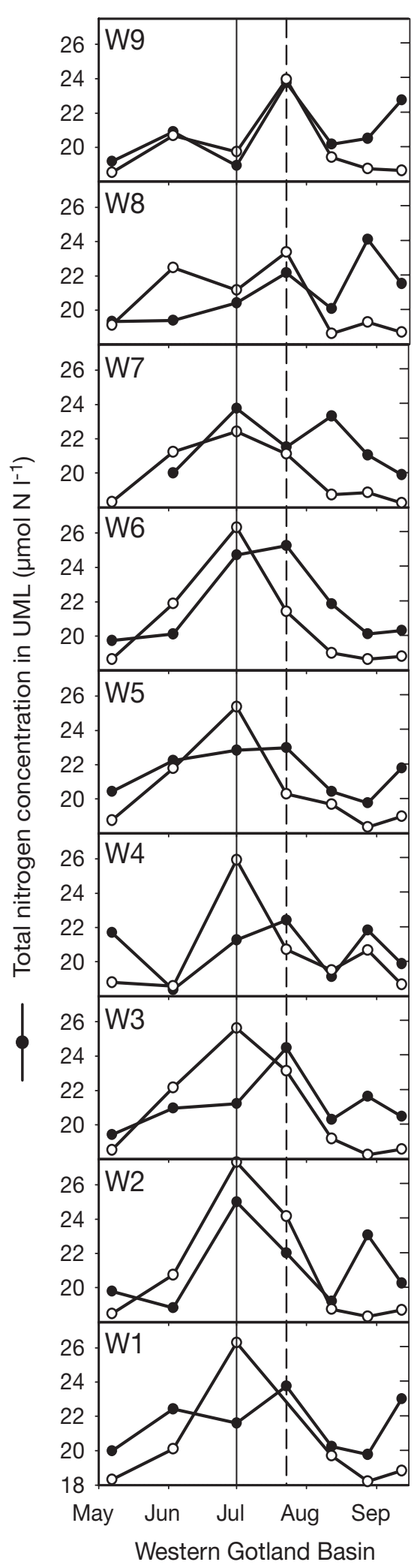

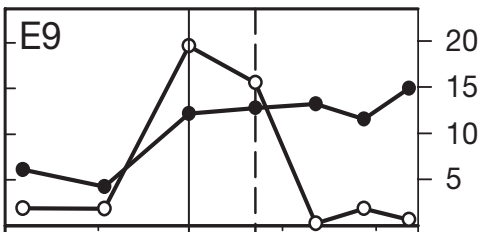
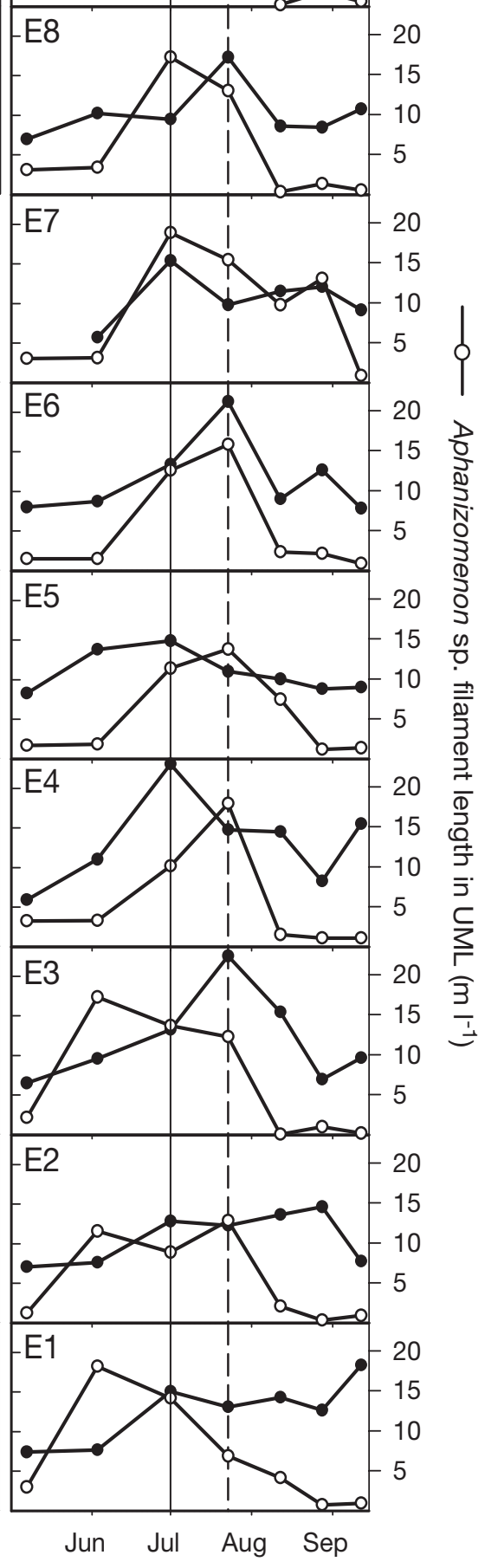

Eastern Gotland Basin

Fig. 7. Total nitrogen concentration and Aphanizomenon sp. abundance in the UML at individual stations (W1-W9, E1-E9) in 2002. Vertical lines indicate average maximum of Aphanizomenon sp. abundance (solid line) and nitrogen concentration (dashed line)

3.2 $\mu \mathrm{mol} \mathrm{N} \mathrm{l}^{-1}$ ) greater than the peak concentration in 2002, assuming that the initial total nitrogen concentration was similar between years. This means separating 23.2 from $24.8 \mu \mathrm{mol} \mathrm{N} \mathrm{l^{-1 }}$ in the WGB, or 24 from $25.6 \mu \mathrm{mol} \mathrm{N} \mathrm{^{-1 }}$ in the EGB, which would require 16 replicates using the same spatial scale as this study ( 5 nm). Similar calculations can be made for different levels of increase (Fig. 8), and the required number of replicates increases rapidly with precision demands, such that detecting a $10 \%$ change requires $\sim 400$ replicates.

Because the difference in Aphanizomenon sp. abundance between basins was small, a common maximum abundance $\left(\sim 15 \mathrm{~m} \mathrm{l}^{-1}\right.$ of filament) can be calculated for July 1 . The pooled SD is large $(\sim 5.4)$, but since changes in abundance are also large, the precision of the samples is good. The number of replicates required to detect a $50 \%$ change in peak abundance is $\sim 10$, which is slightly less than that required for total nitrogen concentration increase (Fig. 8). It should be remembered that although Aphanizomenon sp. is the dominant species, the increase in total nitrogen in the UML estimates fixation by all nitrogen-fixing species. Power calculations from highly replicated data sets of this kind are essential in order to scale monitoring programs to desired levels of detection.

The similarity between WGB and EGB in both total nitrogen concentration and abundance of Aphanizomenon sp. (Fig. 4) suggests that sampling programs can be designed without separating these basins. Pooling of samples reduces variation because the small-scale variation is eliminated, and each individual pooled sample can-according to the central limit theorem-be assumed to belong to an approximately normal distribution of means. The SD of pooled samples can be seen as a SE (standard error) that relates to the true SD between individual hose samples, because $\mathrm{SE}=$ $\mathrm{SD} /(\mathrm{n})^{1 / 2}$, where $\mathrm{n}$ is the number of pooled hoses (in this study, $\mathrm{n}=3$ ). In a time series of coastal samples with 6 replicates of non-pooled hoses at 1 station (L. Almesjö \& C. Rolff unpubl.), a maximum of $\sim 13.1 \mathrm{~m} \mathrm{l}^{-1}$ with a SD of 1.28 was found. 


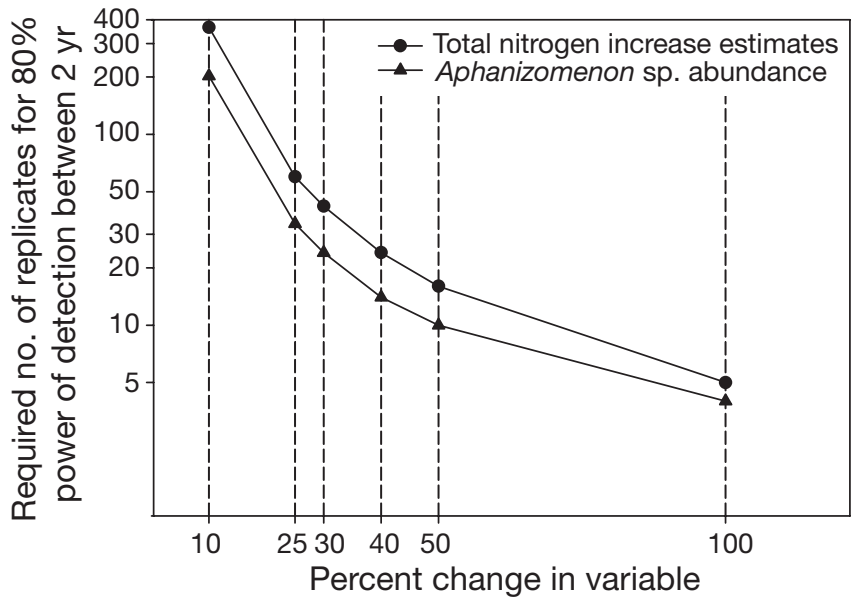

Fig. 8. Power curves (required no. of replicates) for detecting

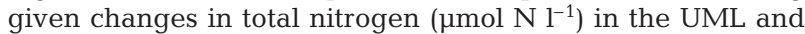
Aphanizomenon sp. abundance ( $\mathrm{m} \mathrm{l}^{-1}$ of filament). Magnitude of change given as \% of observed maximum values in 2002 (see text for further explanation). Note log scale for required no. of replicates

The expected SD of 3 such pooled hoses would have been $1.28 /(3)^{1 / 2}=0.74$, which is only $58 \%$ of 1.28 . The pooled SD of all 18 replicates in WGB and EGB in 2002, at maximum abundance of Aphanizomenon sp. (July 1), was 5.4 and included variation in abundance over distances of $\sim 100 \mathrm{~nm}$ (Fig. 1). If the small-scale variation at maximum abundance is similar in the open sea and at the coastal station, such pooling would thus decrease the total SD by at least $\sim 10 \%$ [(1.28 $0.74) / 5.4]$ and at most by $42 \%\left[1-1 /(3)^{1 / 2}\right]$, which is an important gain in precision. Since pooled estimates can be assumed to come from an approximately normal distribution, pooling also increases the power of tests by facilitating the use of high-power statistical methods such as ANOVA and regression. Pooling of hose samples is highly cost-efficient because it requires little time at sea and the gain in precision can be considerable.

\section{CONCLUSIONS}

Blooms of nitrogen-fixing filamentous cyanobacteria are major sources of nitrogen input to the eutrophicated Baltic Proper. In 2002, filamentous cyanobacteria were estimated to fix 310 ktons $\mathrm{N} \mathrm{yr}^{-1}$ in the Baltic Sea, equivalent to more than one-third of total external load. Only a minor fraction of total nitrogen increase in the UML can be assumed to remain in the biomass of nitrogen fixers. Because sedimentation in the bloom period is low and inorganic nitrogen concentrations are close to the detection limit, it is likely that most of the nitrogen fixed by blooms leaks from the cyanobac- teria and plays a major role in maintaining a high nondiazotrophic phytoplankton production. This production will eventually also stimulate fish production. Blooms also contribute substantially to the Baltic nitrogen load (and hence eutrophication), as well as being a serious water quality problem, hampering waterbound recreational activities and posing a toxin threat. There is a common perception and some evidence that blooms have increased in intensity and duration as a result of increased phosphate concentrations. However, scientific information on spatio-temporal variations of the blooms is fragmentary, and we cannot determine with certainty if the blooms are indeed escalating. This study indicates that detection of a $50 \%$ between-year change in bloom size or nitrogen fixation requires a basin-wide sampling effort of $\sim 10$ to 20 replicates at biweekly intervals during the bloom. Considering the huge cost of eutrophication abatement measures, it should be a top priority to ascertain on a year-by-year basis how the blooms are affected by natural weather conditions, phosphate availability and changes in anthropogenic loads.

Acknowledgements. Support was provided by the MARE project of the Swedish Foundation for Strategic Environmental Research (MISTRA), the European Commission's Environment and Sustainable Development Programme, project SIGNAL (EVK3-CT-1999-00020), and the Stockholm Marine Research Centre. We thank the national Swedish marine monitoring program for time series data from BY31, L. Adelsköld, B. Crona, J. Gardeström and M. Löf for technical help, and the analytical staff of the Department of Systems Ecology at Stockholm University for nutrient data. The crews of RV 'Fyrbyggaren' and RV 'Baltica' are thanked for their helpfulness during cruises. A. Bignert, S. Hansson, L. Kautsky, O. Lindahl and U. Larsson made valuable comments on the manuscript.

\section{LITERATURE CITED}

Bianchi TS, Engelhaupt E, Westman P, Andren T, Rolff C, Elmgren R (2000) Cyanobacterial blooms in the Baltic Sea: natural or human-induced? Limnol Oceanogr 45:716-726

Capone DG, Ferrier MD, Carpenter EJ (1994) Amino-acid cycling in colonies of the planktonic marine cyanobacterium Trichodesmium thiebautii. Appl Environ Microbiol 60:3989-3995

Edler L (1979) Recommendations on methods for marine biological studies in the Baltic Sea. Phytoplankton and chlorophyll. Balt Mar Biol Publ 5:1-38

Finni T, Kononen K, Olsonen R, Wallström K (2001) The history of cyanobacterial blooms in the Baltic Sea. Ambio 30: 172-178

Gallon JR, Evans AM, Jones DA, Albertano P, Congestri R, Bergman B, Gundersen K, Orcutt KM (2002) Maximum rates of $\mathrm{N}_{2}$ fixation and primary production are out of phase in a developing cyanobacterial bloom in the Baltic Sea. Limnol Oceanogr 47:1514-1521

Glibert PM, Bronk DA (1994) Release of dissolved organic nitrogen by marine diazotrophic cyanobacteria, Trichodesmium spp. Appl Environ Microbiol 60:3996-4000 
Granat L (2001) Deposition of nitrate and ammonium from the atmosphere to the Baltic Sea. In: Wulff F, Rahm LA, Larsson P (eds) A systems analysis of the Baltic Sea. SpringerVerlag, Berlin, p 133-148

Gustafsson Ö, Andersson P, Roos P, Kukulska Z, Broman D, Larsson U, Hajdu S, Ingri J (2004) Evaluation of the collection efficiency of upper ocean sub-photic-layer sediment traps: a 24-month in situ calibration in the open Baltic Sea using Th-234. Limnol Oceanogr Methods 2:62-74

Hajdu S, Höglander H, Larsson U (2007) Phytoplankton vertical distributions and composition in Baltic Sea cyanobacterial blooms. Harmful Algae 6:189-205

Heiskanen AS, Kononen K (1994) Sedimentation of vernal and late summer phytoplankton communities in the coastal Baltic Sea. Arch Hydrobiol 131:175-198

Heiskanen AS, Haapala J, Gundersen K (1998) Sedimentation and pelagic retention of particulate $\mathrm{C}, \mathrm{N}$ and $\mathrm{P}$ in the coastal northern Baltic Sea. Estuar Coast Shelf Sci 46: 703-712

HELCOM (Helsinki Commission) (2004) The fourth Baltic Sea pollution load compilation (PLC-4). Balt Sea Environ Proc No 93

Hübel H, Hübel M (1995) Blaualgen-Wasserblüten in der Ostsee: Ursachen-Ausmass-Folgen. Dtsch Hydrogr Z (Suppl) 2:151-158

Janson S, Carpenter EJ, Bergman B (1994) Fine-structure and immunolocalization of proteins in Aphanizomenon sp. from the Baltic Sea. Eur J Phycol 29:203-211

Kahru M, Horstmann U, Rud O (1994) Satellite detection of increased cyanobacteria blooms in the Baltic sea: Natural fluctuation or ecosystem change? Ambio 23:469-472

Kahru M, Leppänen JM, Rud O, Savchuk OP (2000) Cyanobacteria blooms in the Gulf of Finland triggered by saltwater inflow into the Baltic Sea. Mar Ecol Prog Ser 207:13-18

Kanoshina I, Lips U, Leppänen JM (2003) The influence of weather conditions (temperature and wind) on cyanobacterial bloom development in the Gulf of Finland (Baltic Sea). Harmful Algae 2:29-41

Kononen K, Kuoparinen J, Mäkele K, Laanemets J, Pavelson J, Nõmman S (1996) Initiation of cyanobacterial blooms in a frontal region at the entrance to the Gulf of Finland, Baltic Sea. Limnol Oceanogr 41:98-112

Larsson U, Hajdu S, Walve J, Elmgren R (2001) Baltic Sea nitrogen fixation estimated from the summer increase in upper mixed layer total nitrogen. Limnol Oceanogr 46: $811-820$

Lindahl O (1986) A dividable hose for phytoplankton sampling. ICES CM 1986/L:26

Lindfors V, Joffre SM, Damski J (1993) Meteorological variability of the wet and dry deposition of sulphur and nitrogen compounds over the Baltic Sea. Water Air Soil Pollut 66:1-28

Lindström G (1855) Bidrag till kännedomen om Östersjöns invertebratfauna. Övfersigt af Kongl. Vetenskapsakad. Förhandlingar 12:49-73

Moisander PH, Steppe TF, Hall NS, Kuparinen J, Paerl HW (2003) Variability in nitrogen and phosphorus limitation for Baltic Sea phytoplankton during nitrogen-fixing cyanobacterial blooms. Mar Ecol Prog Ser 262:81-95

Niemi A (1979) Blue-green algal blooms and N:P ratio in the Baltic Sea. Acta Bot Fenn 110:33-49

Editorial responsibility: Howard Browman (Associate Editorin-Chief), Storebø, Norway
Niemistö LI, Rinne I, Melvasalo T, Niemi Å (1989) Blue-green algae and their nitrogen fixation in the Baltic Sea in 1980, 1982 and 1984. Meri 17:1-59

Ohlendieck U, Stuhr A, Siegmund H (2000) Nitrogen fixation by diazotrophic cyanobacteria in the Baltic Sea and transfer of the newly fixed nitrogen to picoplankton organisms. J Mar Syst 25:3-4

Poutanen EL, Nikkilä K (2001) Carotenoid pigments as tracers of cyanobacterial blooms in recent and post-glacial sediments of the Baltic Sea. Ambio 30:179-183

Rahm L, Jonsson A, Wulff F (2000) Nitrogen fixation in the Baltic proper: an empirical study. J Mar Syst 25:239-248

Rolff C (2000) Seasonal variation in $\delta^{13} \mathrm{C}$ and $\delta^{15} \mathrm{~N}$ of sizefractionated plankton at a coastal station in the northern Baltic proper. Mar Ecol Prog Ser 203:47-65

Rydin E, Hyenstrand P, Gunnerhed M, Blomqvist P (2002) Nutrient limitation of cyanobacterial blooms: an enclosure experiment from the coastal zone of the NW Baltic proper. Mar Ecol Prog Ser 239:31-36

Schneider B, Nausch G, Nagel K, Wasmund N (2003) The surface water $\mathrm{CO}_{2}$ budget for the Baltic Proper: a new way to determine nitrogen fixation. J Mar Syst 42:53-64

Sellner KG (1997) Physiology, ecology, and toxic properties of marine cyanobacteria blooms. Limnol Oceanogr 42: 1089-1104

Sellner KG, Olson MM, Kononen K (1994) Copepod grazing in a summer cyanobacteria bloom in the Gulf of Finland. Hydrobiologia 292/293:249-254

Sokal RR, Rohlf FJ (2000) Biometry: the principles and practice of statistics in biological research, 3rd edn. WH Freeman, New York

Tuomainen JM, Hietanen S, Kuparinen J, Martikainen PJ, Servomaa K (2003) Baltic Sea cyanobacterial bloom contains denitrification and nitrification genes, but has negligible denitrification activity. FEMS Microbiol Ecol 45: $83-96$

Utermöhl H (1958) Zur Vervollkommnung der quantitativen Phytoplankton-Methodik. Mitt Int Ver Theor Angew Limnol 9:1-38

Voss M, Emeis KC, Hille S, Neumann T, Dippner JW (2005) Nitrogen cycle of the Baltic Sea from an isotopic perspective. Global Biogeochem Cycles 19:GB3001, doi:3010. 1029/2004GB002338

Walsby AE, Hayes PK, Boje R, Stal LJ (1997) The selective advantage of buoyancy provided by gas vesicles for planktonic cyanobacteria in the Baltic Sea. New Phytol 136:407-417

Wasmund N (1997) Occurrence of cyanobacterial blooms in the Baltic Sea in relation to environmental conditions. Int Rev Gesamten Hydrobiol 82:169-184

Wasmund N, Uhlig S (2003) Phytoplankton trends in the Baltic Sea. ICES J Mar Sci 60:177-186

Wasmund N, Voss M, Lochte K (2001) Evidence of nitrogen fixation by non-heterocystous cyanobacteria in the Baltic Sea and re-calculation of a budget of nitrogen fixation. Mar Ecol Prog Ser 214:1-14

Wasmund N, Nausch G, Schneider B, Nagel K, Voss M (2005) Comparison of nitrogen fixation rates determined with different methods: a study in the Baltic Proper. Mar Ecol Prog Ser 297:23-31

Submitted: April 10, 2006; Accepted: June 28, 2006

Proofs received from author(s): February 15, 2007 